\title{
Ethnoichthyology of Fishing Communities in the Lower Valley of Ouémé in Benin, West Africa
}

\author{
Gildas Djidohokpin ${ }^{1 *}$, Edmond Sossoukpè $^{1}$, Richard Adandé ${ }^{1}$, Juste V. Voudounnou ${ }^{2}$, Emile D. Fiogbé ${ }^{1}$, and Anne Haour ${ }^{3}$ \\ ${ }^{1}$ Laboratory of Research on Wetlands, Department of Zoology, Faculty of Sciences and Technics, University of Abomey- \\ Calavi, Cotonou, Republic of Benin. ${ }^{2}$ Aquaculture School of National University of Agriculture, Kétou, Republic of Benin. \\ ${ }^{3}$ Sainsbury Research Unit for the Arts of Africa, Oceania and the Americas, University of East Anglia, Norwich, United \\ Kingdom. \\ "'gdjidohokpin@gmail.com
}

\begin{abstract}
Ethno-ichthyological knowledge can improve fisheries management. This study covers interactions between ecological, morphological, and sociocultural aspects pertaining to the fish of the Tovè River, which is located in the largest fishing area in the Republic of Benin (Ouémé Valley), West Africa. In particular, data were collected on fishing methods and techniques, fishing equipment, and ichthyofauna by noting vernacular names followed by identification traits, taste and dietary value, medicinal use, and related knowledge of different species. Through data related to names given locally to fish, this paper highlights the manner in which physical or behavioral traits are coded in terminology. Most of these species have a high market value, either because they are considered to be delicacies and/or for their medicinal uses. The results suggest that ethno-ichthyological information can successfully be applied to improve fish conservation and fisheries management.
\end{abstract}

Received March 21, 2020

OPEN ӘACCESS

Accepted September 23, 2020

DOI 10.14237/ebl.11.1.2020.1686

Published October 16, 2020

Keywords Ethnobiology, Artisanal fisheries, Indigenous fishing knowledge, Tovè River, Ouémé River

Copyright (c) 2020 by the author(s); licensee Society of Ethnobiology. This is an open-access article distributed under the terms of the Creative Commons Attribution-NonCommercial 4.0 International Public License (https://creativecommons.org/licenses/by-nc/4.0), which permits non-commercial use, distribution, and reproduction in any medium, provided the original author and source are credited.

\section{Introduction}

Human populations have always interacted closely with the ecosystems in which they participate, including aquatic resources, and they exhibit a diverse, nuanced, and deep knowledge of them (Berkes 2008; Turner and Berkes 2006).

Many communities have developed complex systems of resource management and use that have encouraged social and ecological resilience. Such local and traditional ecological knowledge can therefore be a source of information on the current status of resources, local ecosystem dynamics and environmental characteristics, species diversity, species behavior, and interactions among components of ecosystems. Several terms have been used to describe the knowledge of local ecological systems, which is typically accumulated through a long series of observations and transmitted from generation to generation (Berkes 2008; Gadgil et al. 1993). These terms include native knowledge, Indigenous knowledge, traditional (ecological) knowledge, and local knowledge (Castillo et al. 2018; Lima et al. 2017; Oishi 2016; Seixas and Begossi 2001). Oberndorfer et al. (2017) highlight the importance of plants to circumpolar peoples and demonstrate the connections between plants, fishing, and people in the Inuit community of Makkovik, Canada. Drawing on Indigenous methodologies, a local collective narrative traces the links between plants and various fishing activities and demonstrates the power of collective knowledge to connect people to their communities and to their surrounding environments. These studies provide a basis for understanding how the conceptualization of living organisms may be affected by different cultural backgrounds and individual expertise (Medin et al. 2006).

In such dynamic systems, fishers can detect changes in fish behavior, abundance, and distribution. Fishing communities have been shown to have a wellestablished knowledge of fish biology and 
classification (see e.g., Begossi and Garavello 1990, Paz and Begossi 1996 for studies in Brazil; Johannes 1981 for a case study in Palau, Micronesia). Such information, if interpreted using a biological sciences framework, may provide fruitful insights to biologists (Johannes 1993). Researchers have demonstrated that qualitative data from fishers complements scientific information gathered by conventional biological and ichthyological studies (Johannes et al. 2000), improves decision-making (Bergmann et al. 2004; Berkes et al. 2001), and enhances the development of better conservation and management strategies for smallscale fisheries. For example, recently, a team of archaeologists, historical ecologists, and marine biologists used a local fishing community's knowledge to identify shifting baselines and vulnerable coral reef fish species along the Kenyan coast (Buckley et al. 2019). Another example is provided by the work of Johannes (1981) which showed that Pacific Island fisher's information regarding marine fish reproduction helped scientists in the management of fish stocks. The relationships of Indigenous peoples to the ecosystems they live in not only reflects an intimate knowledge of the ecology of those systems, but the deep structure of their beliefs about their role in the world, their cosmology and values, and their social institutions and relationships (Berkes 2008).

Despite the examples cited above, fisher's knowledge has not yet been formally incorporated into management policies for marine environments (Bergmann et al. 2004; Leite and Gasalla 2013; Silvano and Begossi 2010) or in the freshwater realm (Allison and Badjeck 2004). This is partly because agencies and academics lack appreciation of the importance of such ethno-ichthyological data. In addition, conventional management approaches tend to undervalue fisher's knowledge in various ways (Castillo et al. 2018). Research has been limited by a shortage of experts in the field, cultural barriers, and changing political and institutional scenarios (Baigún 2015; Castillo et al. 2016). This poor level of understanding of biological folk knowledge is problematic, not least because such knowledge is under threat from the disappearance of Indigenous people and their customs, as well as from the influence of urbanization and the market economy on resource-use strategies (Johannes 1978; Posey 1983; Wester and Yongvanit 1995).

In this context, ethno-ichthyological studies can serve as a valuable management tool, bringing to light information that can provide both guidelines for biological research (Marques and Wanderley 1991; Poizat and Baran 1997) and as a quick and costeffective way to assess biological data (Chapman 1987; Johannes 1981). To contribute to this developing set of research, the present paper will focus on the interactions between the ecological, morphological, and sociocultural aspects around the fish of the Tovè River in southern Benin, West Africa. It is the first study of its kind in this region, and one that might be helpful for fisheries management and the wellbeing of fishing communities there. The Tovè River is a tributary of the lower valley of the Ouémé River, the largest river in Benin and today considered the second most fertile valley in the world after the Nile in Egypt (UNDP Benin 2015). It was chosen as a case study due to its significance to its waterside communities with respect to fishery and agricultural zones. The species in the Tovè River are usually harvested by local people using gillnets and represent a high-value food source. This echoes the situation in Benin more widely: the resources offered by the various rivers and water bodies are varied (e.g., comprising fish, mollusks, and crustaceans) and these are intensively used by communities. They account for almost 35\% of the needs estimated at 113,000 tons per year of animal protein (FAO 2008). Among these resources, fish alone account for 31.9\% (FAO 2008). This paper will introduce the study area and data collection strategy, then present the names used to designate fish, their possible origin, fishing techniques, and different uses of fish. The results are then discussed, first within the context of the Tovè River and the wider Ouémé system of which it is a part of, and then more globally.

\section{Methodology}

Study Area

The Tovè River is located in southern Benin and lies in the lower part of the Ouémé River, the largest river basin in Benin. With an approximate length of $1 \mathrm{~km}$, and an average width of $3 \mathrm{~m}$, the Tovè River rises in the swamp of Tovè at Tovègbamè and flows into the Ouémé River (Figure 1). The Tovè River is entirely representative of the much larger Ouémé with respect to its specific diversity (Djidohokpin et al. 2017). With its vast flood plains, the Lower Ouémé Valley favors an important colonization by fish (Lalèyè et al. 2007). Fishing in this area has been practiced for thousands of years and is carried out by Toffin, Wémè, and Goun communities. This activity remains artisanal 


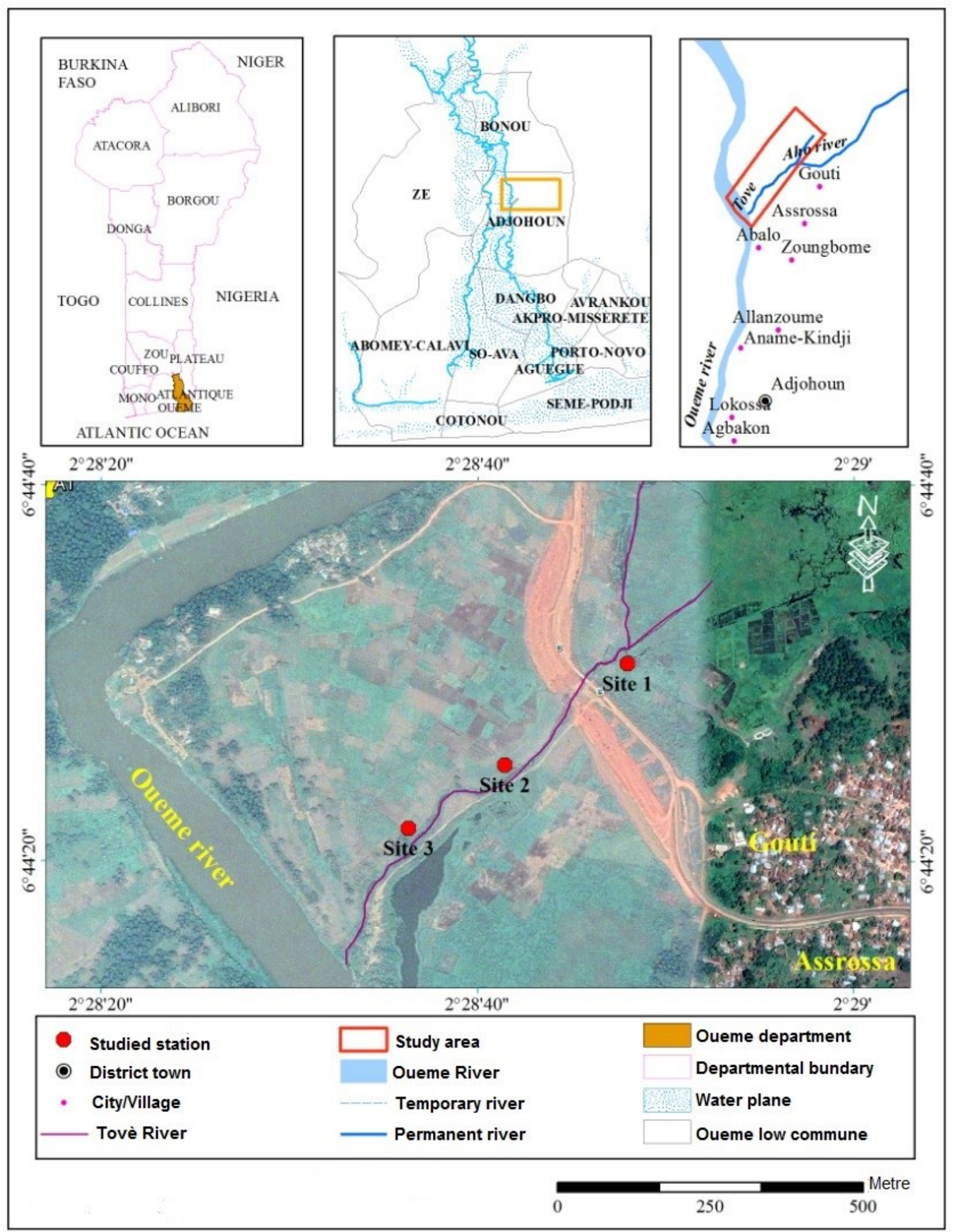

Figure 1 The study area of the project, which is located in the Lower Valley of Ouémé in Benin, West Africa. 
with the use of various gear and fishing techniques (Sohou et al. 2009).

Some portions of the river are intensively and repeatedly exploited for fishing. They were chosen for the present study based on their proximity to fisher's agglomerations, their accessibility and the existence of a landing stage, and proof of the effectiveness of the fishing activity. Three fishing areas (Sites 1, 2, and 3) have been identified that met the relevant criteria (Figure 1).

\section{Sampling and Data Collection}

Fish were collected monthly from October 2015 to September 2016 (Djidohokpin et al. 2017). Sampling was mainly based on artisanal fishery catches. Collected specimens were taken to the Laboratory of Research on Wetlands (LRZH), Department of Zoology, Faculty of Science and Technology at the University of Abomey-Calavi and were identified using identification keys (Djidohokpin et al. 2017). Following the identification process, the species chosen as a focus of this study were those which were abundant in the river (Djidohokpin et al. 2017) and were primarily known for their market value.

Participatory observation was undertaken on fishing activities on the landing stages of selected fishing areas on both long-term and distant fishing expeditions, and daily fishing activities close to the village. During this participation, data was collected on fishing methods and techniques, on fishing equipment, and on ichthyofauna by noting their local name, food and medicinal use, and any the other relevant knowledge of the different species. According to Berlin (1973, 1992), folk genera constitute groups of animals or plants that are easily recognized on the basis of a large number of broad morphological characteristics, usually described using
Table 1 Sample questionnaire. Total interviews with fishers $=n$.

\begin{tabular}{l}
\hline Question \\
\hline 1. Name of Interviewee \\
2. Gender \\
3. Place of Residence \\
4. What is the local name of this fish? \\
5. What is the origin of the vernacular name? \\
6. Traditional Uses of Fish \\
a. Do you eat this species? \\
b. Do you use the species in traditional medicine?
\end{tabular}

primary names (monomials). Distinguishing folk species, on the other hand, requires more detailed observation on the basis of very few morphological characters, and they are typically described using binomials (i.e., the generic name is modified by an adjective which usually describes some obvious morphological character) (Berlin 1973, 1992). In the present study, the analysis of folk and scientific systems of classification had the scientific species and the folk genus as the basic taxa, as proposed by Berlin (1973).

Interviews were carried out with men and women who fish now or had fished in the past. A standardized questionnaire (see Table 1 for an example questionnaire) was developed and the questions were asked in a manner understandable to the fishers interviewed, who were allowed to answer taking as much time as they wanted. The duration of interviews varied, depending on the knowledge and time constraints of the interviewees. The number of interviewees varied slightly according to the different fish species and because some people could not complete the questionnaire.

Table 2 Fish species (including family and local names) used in the interviews.

\begin{tabular}{llll}
\hline Scientific Name & Family & Local Name & Common Name \\
\hline Parachana obscura & Channidae & Hotoun & African Obscure Snakehead \\
Clarias gariepinus & Clariidae & Asson & Common Catfish \\
Brycinus longipinnis & Characidae & Agontcha & African Longfin \\
Chrysichthys auratus & Claroteidae & Djan & Golden Nile Catfish \\
Heterotis niloticus & Osteoglossidae & Houa & African Bonytongue \\
Sarotherodon melanotheron & Cichlidae & Wè & Blackchin Tilapia \\
Synodontis schall & Mochokidae & Gloé & Wahrinda \\
Malepterurus electricus & Malapteruridae & Zègbin & Electric Cattish \\
Labeo senegalensis & Cyprinidae & Adahoué & African Carp \\
Hepsetus odoe & Hepsetidae & Kaka-adou & African Pike \\
\hline
\end{tabular}


Table 3 Origins of vernacular names for fish species used for interviews.

\begin{tabular}{|c|c|c|c|}
\hline Reasons for Local Name & Local Name & Scientific Name & Picture of Species \\
\hline \multicolumn{4}{|l|}{$\begin{array}{l}\text { Denomination motivated by } \\
\text { physical appearance }\end{array}$} \\
\hline $\begin{array}{l}\text { Denomination motivated by } \\
\text { resemblance to the snake }\end{array}$ & Hotoun & Parachana obscura & \\
\hline $\begin{array}{l}\text { Denomination motivated by } \\
\text { resemblance to the cat }\end{array}$ & Asson & Clarias gariepinus & \\
\hline $\begin{array}{l}\text { Denomination motivated by } \\
\text { the prominence of a fan- } \\
\text { shaped dorsal fin }\end{array}$ & Agontcha & Brycinus longipinnis & \\
\hline $\begin{array}{l}\text { Denomination motivated by } \\
\text { the prominence of a mouth } \\
\text { covered with scabies }\end{array}$ & Adahoué & Labeo senegalensis & \\
\hline $\begin{array}{l}\text { Denomination motivated by } \\
\text { the prominence of a dented } \\
\text { head }\end{array}$ & Djan & Chrysichthys auratus & \\
\hline $\begin{array}{l}\text { Denomination motivated by } \\
\text { the presence of electric organs }\end{array}$ & Zègbin & Malepterurus electricus & \\
\hline $\begin{array}{l}\text { Denomination motivated by } \\
\text { the presence of a shield on the } \\
\text { body }\end{array}$ & Gloé & Synodontis schall & \\
\hline $\begin{array}{l}\text { Denomination motivated by } \\
\text { the presence of a black spot on } \\
\text { the operculum }\end{array}$ & Wè & $\begin{array}{l}\text { Sarotherodon } \\
\text { melanotheron }\end{array}$ & \\
\hline
\end{tabular}

(continued on next page) 
(continued from previous page)

\begin{tabular}{llll}
\hline Reasons for Local Name & Local Name & Scientific Name & Picture of Species \\
\hline Denomination motivated by & & \\
$\begin{array}{l}\text { Denomination motivated by its } \\
\text { habit of hiding under swamp } \\
\text { vegetation }\end{array}$ & Houa & Heterotis niloticus \\
$\begin{array}{l}\text { Denomination motivated by } \\
\text { the sound it emits when caught }\end{array}$ & Kaka-adou & Hepsetus odoe & \\
& & \\
\end{tabular}

\section{Results}

The selection criteria listed above enabled the selection of ten species from different families corresponding to $52 \%$ of the families, $34 \%$ of genera, and $22 \%$ of the species reported in the river during previous studies (Djidohokpin et al. 2017). The simple random sampling method was used to select to 150 men and 30 women for interviews, corresponding to about $80 \%$ of the residents who fished in the eight small villages studied: Gouti, Assrossa, Abalo, Zoungbomè, Allanzoumè, Aname-kindji, Lokossa, and Agbakon located along the Ouémé River and its tributaries. In the Ouémé Valley, fishers gather in small groups of the same ethnicity, forming small villages. The villages chosen for this study are those with a real impact on the river, considering, among other things, the relative importance of fishing among income-generating activities, the demographic weight of each village, the geographic position in relation to the river, and dominant socio-cultural groups that fish on this river.

\section{Local Fish Names}

The general name for a fish in Fon is Hwevi. Names also exist for broader groups. For example, dò hwevi refers to benthic fish. Freshwater resources of the valley of the Ouémé are extremely diverse, and so are the ichthyological knowledge systems that are conceived by the Indigenous fishers. Local names of fish may correspond to biological species or biological families or may include fish of different families and combinations of species.

Local and scientific names are listed in Table 2. Only the most commonly spoken dialect in the study area, Wémè, a Fon language, has been retained for the study. Indeed, the fishing community of the study area is mainly made up of Wémènu and related ethnic groups $(97.3 \%)$, with a minority of Aizo and Adja $(1.4 \%)$, and Yoruba (1.2\%) immigrants (Adéoti et al. 2018).

\section{Origins of Vernacular Names}

The processes that explain ethno-ichthyological denominations by traditional populations derive from a detailed knowledge of fish morphology. In general, denominations summarize the physical or behavioral traits of fish. For this reason, fishers recognize or name species according to different characteristics associated with ecological, morphological or biological traits (Table 3).

\section{Fishing Methods}

From simple angling carried out individually to sophisticated dams and platforms built collectively, the fishers of the Tovè River have elaborated and sometimes borrowed a valuable diversity of fishing methods from other groups. Fishing equipment and techniques are used by these fishers to remove fish and other fish resources from the river for marketing, healing, and/or consumption. Nine fishing equipment, techniques and methods were recorded on the Tovè River.

The fishing equipment and techniques are described in Table 4 with special reference to their ecological knowledge.

\section{Food and Medicinal Uses of Fish}

Fishing work in this area is often gendered. When the fishers land their catch, they, often a male, sell it to the first link in the circuit: his wife or another woman. These women resell the same fish to traders who come to landings very early in the morning or in the 
Table 4 Fishing equipment and techniques frequently used in the study area.

\begin{tabular}{|c|c|c|c|c|}
\hline Fishing Equipment & Local Name & $\begin{array}{l}\text { Fishing Method and } \\
\text { Technique }\end{array}$ & Picture & $\begin{array}{l}\text { Frequency } \\
\text { of Use }\end{array}$ \\
\hline Fish-trap & Owou & $\begin{array}{l}\text { Traps made with palm or } \\
\text { split bamboo ribs, ar- } \\
\text { ranged along a palm } \\
\text { branch palisade to capture } \\
\text { fish. The frame is sur- } \\
\text { rounded by a } 1.2 \mathrm{~cm} \text { multi- } \\
\text { filament nylon net of knot } \\
\text {-node knots in which } 2-4 \\
\text { openings are made later- } \\
\text { ally. }\end{array}$ & & {$[+++]$} \\
\hline Branch Parks & Acadja & $\begin{array}{l}\text { Device made from branch- } \\
\text { es and floating vegetation } \\
\text { which attracts schools of } \\
\text { fish that feed on it and } \\
\text { hide there. Nets are then } \\
\text { stretched around the field } \\
\text { to enclose the fish. }\end{array}$ & & {$[+++]$} \\
\hline Fish-hook & Alonouhou & $\begin{array}{l}\text { Fishing rod with a baited } \\
\text { hook. It is mostly used by } \\
\text { women and children from } \\
\text { the bank. }\end{array}$ & & {$[++]$} \\
\hline
\end{tabular}

(continued on next page) 
(continued from previous page)

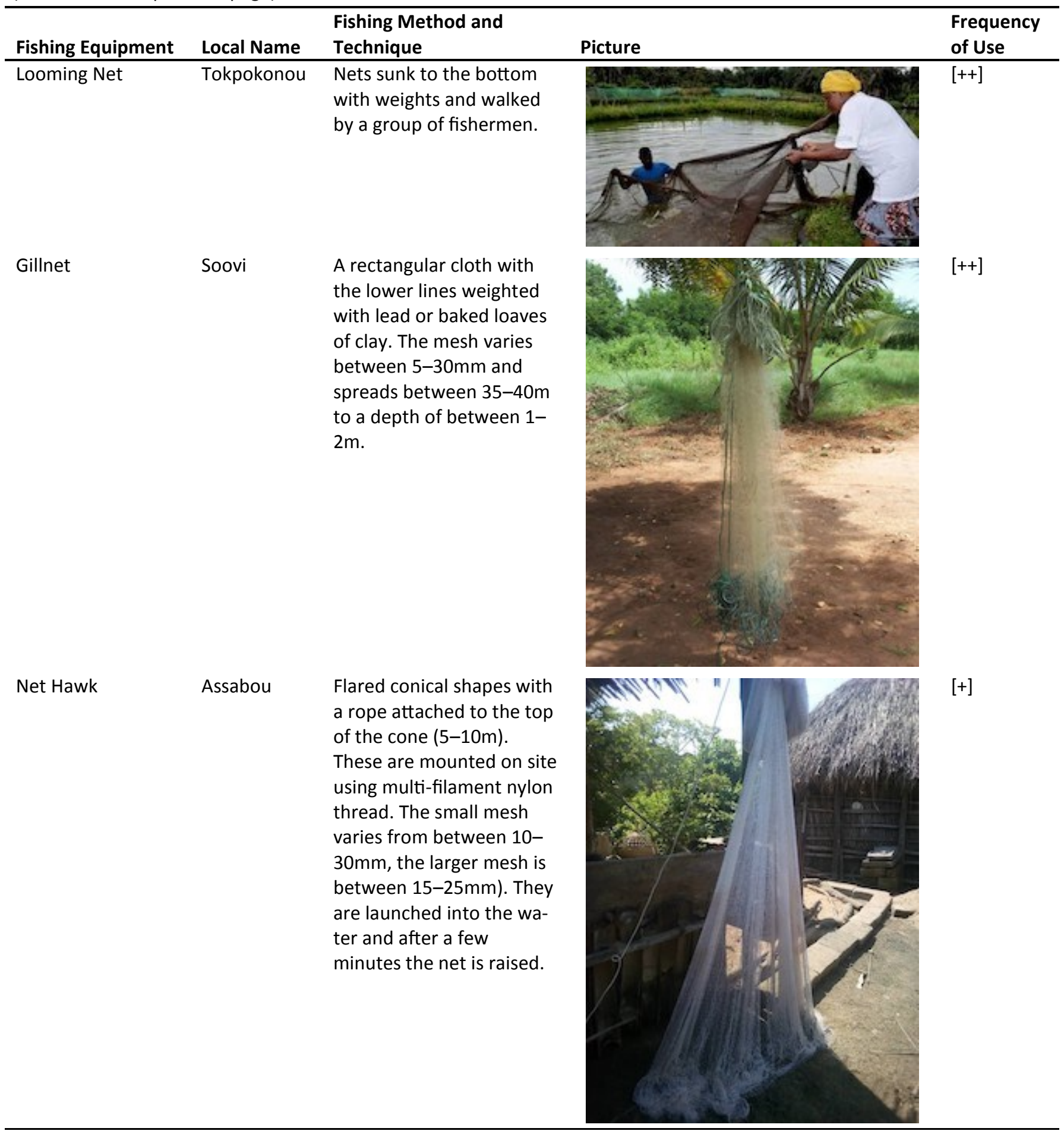


(continued from previous page)

\begin{tabular}{|c|c|c|c|c|}
\hline Fishing Equipment & Local Name & Fishing Method and & Picture & Frequency \\
\hline Longline & Mlin & $\begin{array}{l}\text { Main line of about } 80 \mathrm{~cm} \text {, } \\
\text { to which branchlines are } \\
\text { attached. The lines have a } \\
\text { main wire along which } \\
\text { many branchlines are } \\
\text { attached at regular inter- } \\
\text { vals each with baited } \\
\text { hooks on the end. }\end{array}$ & & {$[+]$} \\
\hline Barrels & Gbadja & $\begin{array}{l}\text { Barrels are } 75 \mathrm{~cm} \text { long, } \\
\text { pierced with a hole }(15 \mathrm{~cm} \\
\text { radius) and covered with a } \\
50 \mathrm{~mm} \text { mesh then baited } \\
\text { with a Chrysichthys. The } \\
\text { sound emitted by the } \\
\text { Chrysichthys attracts oth- } \\
\text { ers which then also be- } \\
\text { come trapped. Two fisher- } \\
\text { men will go back } 3 \text { days } \\
\text { later to remove the con- } \\
\text { tents using a } 5-8 \mathrm{~m} \text { rope } \\
\text { attached to a stake which } \\
\text { holds the barrel. }\end{array}$ & & {$[+]$} \\
\hline Giant Landing Net & Dobah & $\begin{array}{l}\text { This is a large circular } \\
\text { landing net mounted on a } \\
\text { wooden frame attached to } \\
\text { a long handle. It may have } \\
\text { small ( } 5-8 \mathrm{~mm} \text { between } \\
\text { the knots) or large mesh } \\
\text { (20-30mm between the } \\
\text { knots). }\end{array}$ & & {$[+]$} \\
\hline
\end{tabular}

[+++]Very Common.

$[++]$ Common.

[+]Rare. 
evening. This second group of intermediaries may or may not be wholesalers. Either way, they transport the fish to the nearest market, using baskets with a circular lid. As a result of these transactions, the price of fish is increased, because each group wishes to derive the greatest possible benefit. Some fishers prefer to eliminate the intermediaries, and entrust the sale to their wives, who reserve a small part for their own consumption and sell part of the fish on the local or regional market, or alternatively transform the goods before the sale to different customers in order to bring in more profits. This fish processing is a necessity for profitability once consumer taste is taken into account; it is not a speculative choice. Several methods are used, namely smoking, salting-drying, or frying.

Although the Wémènu capture fisheries serve first and foremost to provide animal protein for their own subsistence diet, they also to a lesser extent take part in this trade and constitute a secondary source of cash income. Indeed, the first source of income for local populations is agriculture, and this absorbs most of the available labor. After that, come other secondary activities, such as fishing, especially during the rainy season. In the study area, three categories of fishers share the aquatic resources of the Ouémé river and surrounding rivers. We distinguish professional fishers $(92 \%)$, who devote themselves exclusively to full-time fishing; occasional or seasonal fishers $(5 \%)$, especially young people, who also engage in other activities in the primary sector; and finally amateurs $(3 \%)$, consisting of beginners and those who enjoy recreational fishing (Adeoti et al. 2018).
All fish species in the Tovè River are used for subsistence and/or medicinal purposes. Listed in Table 5 are the species concerned and an indication of their medicinal or food use.

\section{Discussion}

This study represents the first assessment of the ethno -ichthyological knowledge of the lower valley of the Ouémé (Benin) and demonstrates that a large number of binomial names were associated with mostly morphological and ecological attributes.

Morphology was the most frequent category drawn upon to identify fish at the specific level in the folk nomenclature; specific-level names were dominated by morphological attributes such as color. For example, Wè is the local name for Sarotherodon melanotheron; Wě means 'white' in Fon, and the term here relates to the belly of this fish which is often white (see the picture in Table 3). As we discuss below, analogies to things, animals, and, to a lesser extent, shape also occur; names referring to habitat are also important for identifying specific fish. This is comparable with other ethno-taxonomic studies in small-scale fisheries (Aigo and Ladio 2016; Batista et al. 2016; Begossi et al. 2008; Castillo et al. 2018; Clauzet et al. 2007).

The most salient phenotypic and behavioral characteristics of a species are usually reflected in taxonomies. For example, regarding Parachana obscura, informants compare the livery of this fish with the skin of the reptile. Here, they echo ichthyologists who retain the trait "serpentiform" as one of the diagnostic characters of this fish. Similarly, Clarias gariepinus refers

Table 5 Uses for Tovè River fish.

\begin{tabular}{llll}
\hline Scientific Name & Local Name & Food Use & Medicinal Use \\
\hline Parachana obscura & Hotoun & {$[+++]$} & {$[++]$} \\
Clarias gariepinus & Asson & {$[+++]$} & \\
Brycinus longipinnis & Agontcha & {$[++]$} & \\
Chrysichthys auratus & Djan & {$[+++]$} & \\
Heterotis niloticus & Houa & {$[+++]$} & \\
Sarotherodon melanotheron & Wè & {$[+++]$} & \\
Synodontis schall & Gloé & {$[++]$} & {$[+++]$} \\
Malepterurus electricus & Zègbin & & \\
Labeo senegalensis & Adahoué & {$[+]$} & \\
Hepsetus odoe & Kaka-adou & {$[+]$} & \\
\hline
\end{tabular}

[+++]Very Common.

$[++]$ Common.

[+]Rare. 
to a fish called African catfish, and which is often compared to the domestic cat because of its barbels. This resemblance justifies the association with the term Asson, or cat, given locally to this fish. Brycinus longipinnis is a species that, as its Latin name indicates, has a characteristic, almost fan-shaped dorsal fin. This peculiarity lies at the origin of its recognition and its local denomination. Informants describe Labeo senegalensis as the fish with scabies in the mouth. The inflamed mouth suggests a relationship with the local term Adahoue, which designates smallpox, and is characterized by the appearance of pustules on the body. Chrysichthys auratus refers to a species of fish that villagers described by reference to its dented head. The particular shape of the head is therefore the characteristic that distinguishes this species from others. The order to which Chrysichthys belongs, Siluriformes, also indicates a relationship with the skull since, according to Froese and Pauly (2017), the characteristics that allocate a fish to the order of Siluriforms are those of the skull and the swim bladder. The villagers use the term Zìgbin to refer to Malepterurus electricus; this is a species with an electric organ surrounding the whole body. The expression $Z$ ègbin comes from a group of vernacular words which are $Z \breve{e}$ meaning "to rise" and gbingbán which means "clumsily." These two associated expressions convey the unpleasant consequences of touching the fish. This description is consistent with that of the ichthyologists who define Malepterurus electricus as an electric catfish with a large electrical organ along its body. It is the ability of Heterotis niloticus to find refuge under the vegetation of swamps and in fish holes which gives it the name Houa, which means hiding. This observation is in line with that of Micha and Frank (1976) who state that, naturally, this species occurs mainly in the littoral zone where it can find the abundant plant cover necessary for its reproduction.

Freshwater resources of Benin are extremely diverse (Lalèyè et al. 2004), and so are the ichthyological knowledge systems of Indigenous fishers. The fauna of the wetlands of southern Benin consists of a variety of species adapted to the various natural conditions of this biotope. We observed that this induces a high diversity in fishing methods, fishing equipment, and techniques (Table 4). Similar findings resulted from studies conducted by Attingli et al. (2017), Chikou (2006), and Lalèyè et al. (2007), who presented a comprehensive inventory of fishing gear and techniques in the study area.
Each site is exploited on a seasonal basis, but the cumulative diversity of fishing areas ensures fish are continuously caught throughout the year. For instance, several catfish of the Clariidae family take refuge in temporary burrows as an adaptive response to water deoxygenation during the dry season (Chapman et al. 1994), and fishing methods have been devised accordingly. This functional typology puts special emphasis on the water level which is understood by local communities to be the most seasonally varying environmental parameter. Ichthyological science puts forward the fundamental role of the water level in the ecology and behavior of inland rainforest fish in search of available habitats that are mediated by seasonal rains (Chapman 2001). Taking optimal advantage of the watershed, fishers have acquired extensive expertise in adjusting their fishing methods, including diurnal versus nocturnal; permanent versus ephemeral; opportunistic versus controlled; male, female, or mixed; adults versus children; solitary versus pairs; and trinomial or groups including dozens of protagonists.

Fishers distinguish different nets by the size of the mesh, which is calculated using the finger width as a standard unit of measurement. The majority of gillnet fishers possess nets with a 2.5-finger sized mesh that serves for the capture of small- to mediumsized fish for household consumption; very few fishers have larger mesh nets (3.5 to 4-finger sized), which are more adapted to the capture of large fish with scales for the market economy. The beginning of the rainy season is the optimal time for gillnetting because it offers a compromise between the abundance of fish and the more difficult conditions for net stretching. These are the techniques deployed for the longest period in the fishing areas of the Ouémé Valley. The barrel Gbadja and Nasses of are of lesser importance and are used over relatively short periods. These two devices are removed at the latest three days after their installation in order to extract the contents. The appearance of the Gbadja, a new type of fishing gear, reveals a dynamic in the sophistication of fisher's gear and techniques, which is currently directed towards a more random catch. This could be explained by the progressive decline in output reported by some writers in some years (Chikou 2006; Imorou Toko 2007; Lalèyè et al. 2007; Welcomme 1971). These fishing management practices and adaptation strategies are developed by fishers to cope with the disappearance of certain fish 
species, the reduction in the size of the fish taken, the high cost of fish, and the decrease in the abundance of species suitable for processing by drying and smoking.

Hook fishing mostly occurs alongside other fishing activities. It is a means of catching small fish, which in turn serve as bait for catching larger fish via more substantial methods. For instance, women occasionally hook fish during the dry season as a side activity to dam fishing. Whatever the season, longlines are installed in the deep parts of rivers. This is a solitary male activity carried out by fishers who own a canoe. A hundred small gangions are fixed to a long lead rope tied to the branch of an overhanging tree. Pebbles serving as ballasts are tied to each gangion, and hooks are baited with the flesh of small fish or crab. During daylight, the fisher visits the longline continuously. When they realize that a gangion has caught a fish, they tie stretches of bamboo to delay hauling in the fish. While desperately trying to swim away, the fish will become tired by the resistance of the floating bamboo. Nocturnal longlines are installed at sunset following the same method but are visited only once before sunrise.

Fishing gear appears primarily linked to the size of the target species and the seasons, although a more focused study in future would allow an exploration of whether there is also any particular association with specific fish species. Different types of fishing gear are chosen as fishers plan their fishing activities throughout the year, modulating or combining their various fishing methods in accordance with seasonal water level fluctuations and their incidence on watercourse microhabitats. As stressed by Colfer et al. (1999), increased effort should be made to analyze Indigenous ways of perceiving time and scheduling activities accordingly.

All the fish species in the Tovè River are used both for subsistence and for medicinal purposes. The sale of fish may occasionally occur in local markets, but the primary goal of fishing is not aimed at the market economy or at the creation of wealth and income. It is to secure dietary regimes by supplying protein-rich and tasty wild food. Preferences and aversions can be explained by cultural and ecological factors: the availability of the resource, the position of the species in the food chain, or through the importance of these species in the economy and social relationships within the community. For example, the catfish (Clarias gariepinus) is a preferred food in the fishing community, reflecting a complex interplay of symbolic and cultural factors, as well as materialistic or functional factors, such as the environmental abundance of this resource in the region. Although caught primarily as a source of animal protein for their own diet, fishers also take part in this trade to a lesser extent, which constitutes a secondary source of cash income.

Some species of fish such as Malepterurus electricus are not the subject of a specific fishing strategy. Most of these species are used in traditional medicine for the treatment of diseases or for occult practices, so it creates great excitement for the fisher who catches them. The fishers sell these fish for a high price to traditional healers. The fish then undergoes a transformation according to the medical or mystical use for which it is intended. For example, investigations indicate that Malepterurus electricus is used for the treatment of epilepsy, sexual disorders in men, difficult childbirth, and convulsions. Parachana obscura is very often used by traditional healers as a magical tool to prevent women from committing adultery. As Neuenschwander et al. (2011) pointed out, the mystical properties attributed to these types of fish can act as an aphrodisiac.

\section{Conclusion}

The present study reinforces the argument that folk taxonomy represents a valuable and necessary information source, particularly in a large river domain where fish biodiversity is a relevant issue and governmental agencies often lack the reliable human resources needed to tackle multi-species fisheries management.

These results confirm that fishers do retain an important body of knowledge that could support faster and more affordable management initiatives. Moreover, fishers could certainly contribute with additional information where there are no official statistics. Fishers can enhance our understanding of marine ecosystem dynamics and of fisheries in general, which is not easily or cheaply achieved solely by conventional approaches. The Wémènu have elaborated a great variety of fishing techniques that mediatize their extensive knowledge regarding fish ecology, diet, and behavior, in relation to diversified aquatic microhabitats. Most fishing methods are performed in very specific time and place. Each fishing practice requires a proper choice of fishing ground and an adjusted technique. 
It is also imperative to document and interpret fisher's folk knowledge, especially in the tropics, to enable scientists to work together with fishers in devising measures aimed at conserving both fish and fishing cultures.

Finally, further studies should take a closer look at the differences in ethno-ichthyological knowledge between the generations in order to protect and conserve their history in print.

\section{Acknowledgments}

The author is grateful to all who made this study successful. Sincere thanks go to the British Academy which financed a Writing Workshop (Award WW19 $\backslash 100199)$ during which the first author benefited from the mentoring of the editors of journals and academics, in order to prepare this paper.

\section{Declarations}

Permissions: British Academy.

Sources of funding: None declared.

Conflicts of Interest: None declared.

\section{References Cited}

Adeoti, B. O. E., I. Yabi, F. Medeou, and E. Ogouwale. 2018. Caractérisation de la Pêcherie Continentale dans les Communes d'Adjohoun et de Dangbo au sud-est Bénin. Afrique Science 14:170184.

Aigo, J., and A. Ladio. 2016. Traditional Mapuche Ecological Knowledge in Patagonia, Argentina: Fishes and Other Living Beings Inhabiting Continental Waters, as a Reflection of Processes of Change. Journal of Ethnobiology and Ethnomedicine 12:56. DOI:10.1186/s13002-016-0130-y.

Allison, E. H., and M. C. Badjeck. 2004. Livelihoods, Local Knowledge and the Integration of Economic Development and Conservation Concerns in the Lower Tana River Basin. Hydrobiology 527:19-23. DOI:10.1023/b:hydr.0000043314.35885.1e.

Attingli, A. H., S. Ahouansou Montcho, E. W. Vissin, L. H. Zinsou, and P. A. Lalèyè. 2017. Influence des Engins et Techniques de Pêche sur l'Abondance Relative des Espèces dans la Basse Vallée de l'Ouémé au Bénin. African Crop Science Journal 25:4770. DOI:10.4314/acsj.v25i1.4.

Baigún, C. 2015. Guidelines for Use of Fishers' Ecological Knowledge in the Context of the Fisheries Ecosystem Approach Applied to Small-
Scale Fisheries in South America. In Fishers' Knowledge and the Ecosystem Approach to Fisheries: Applications, Experiences and Lessons in Latin America, edited by J. Fischer, J. Jorgensen, H. Josupeit, D. Kalikoski, and C. M. Lucas, pp. 63-83. Fisheries and Aquaculture Technical Paper No. 591, FAO, Rome.

Batista, L. P. P., J. I. S. Botero, and E. P. Oliveira. 2016. Etnotaxonomia and Food Taboos of Artisanal Fishermen in the Dams Araras and Edson Queiroz, River Basin Acaraú, Ceará, Brazil. Entorno Geográfico 12:34-49. DOI:10.25100/eg.v0i12.3543.

Begossi, A., and J. C. Garavello. 1990. Notes on the Ethnoichthyology of Fishermen from the Tocantins River (Brazil). Acta Amazonica 20:341-351. DOI:10.1590/1809-43921990201351.

Begossi, A., M. Clauzet, J. L. Figueiredo, L. Garuana, R. V. Lima, P. F. Lopes, M. Ramires, A. L. Silva, and R. A. M. Silvano. 2008. Are Biological Species and Higher-Ranking Categories Real? Fish Folk Taxonomy on Brazil's Atlantic Forest Coast and in the Amazon. Current Anthropology 29:291-306. DOI:10.1086/527437.

Bergmann, M., H. Hinz, R. E. Blyth, M. J. Kaiser, S. I. Rogers, and M. Armstrong. 2004. Using Knowledge from Fishers and Fisheries Scientists to Identify Possible Ground fish 'Essential Fish Habitats'. Fisheries Research 66:373-379. DOI:10.1016/ j.fishres.2003.07.007.

Berkes, F. 2008. Sacred Ecology, 2nd edition. Routledge, New York.

Berkes, F., R. Mahon, P. McConney, P. Ponnac, and R. Pomeroy. 2001. Managing Small-scale Fisheries: Alternative Directions and Methods. International Development Research Centre Press, Ottawa, Canada.

Berlin, B. 1973. Folk Systematics in Relation to Biological Classification and Nomenclature. Annual Review of Ecology and Systematics 4:259-271. DOI:10.1146/annurev.es.04.110173.001355.

Berlin, B. 1992. Ethnobiological Classification: Principles of Categorization of Plants and Animals in Traditional Societies. Princeton University Press, Princeton, NJ.

Buckley, S. M., T. R. McClanahan, E. M. Quintana Morales, V. Mwakha, J. Nyanapah, L. M. Otwoma, and J. M. Pandolf. 2019. Identifying Species 
Threatened with Local Extinction in Tropical Reef Fisheries using Historical Reconstruction of Species Occurrence. PLoS ONE 14:e0211224. DOI:10.1371/journal.pone.0211224.

Castillo, T. I., C. R. M. Baigún, and P. G. Minotti. 2016. Assessment of a Fisheries Legal Framework for Potential Development of an Ecosystem Approach to Fisheries Management in Large Rivers. Fisheries Management and Ecology 23:510-518. DOI:10.1111/fme.12192.

Castillo, T. I., F. Brancolini, M. Saigo, J. R. Correa, and C. R. M. Baigún. 2018. Ethnoichthyology of Artisanal Fisheries from the Lower La Plata River Basin (Argentina). Journal of Ethnobiology 38:406-423. DOI:10.2993/0278-0771-38.3.406.

Chapman, M. D. 1987. Women's Fishing in Oceania. Human Ecology 15:267-288. DOI:10.1007/ bf00888026.

Chapman, L. J., L. Kaufman, and C. A. Chapman. 1994. Why Swim Upside Down? A Comparative Study of two Mochokid Catfishes. Copeia 1994:130 135. DOI:10.2307/1446679.

Chapman, L. J. 2001. Fishes of African Rain Forests. In African Rain Forest Ecology and Conservation: An Interdisciplinary Perspective, edited by W. Weber, L. J. T. White, A. Vedder, and L. Naughton-Treves, pp. 263-290. Yale University Press, New Haven, CT.

Chikou, A. 2006. Etude de la Démographie et de l'Exploitation Halieutique de Six Espèces de Poissons-chats (Teleostei, Siluriformes) dans le Delta de l'Ouémé au Bénin. Unpublished Doctoral Dissertation, University of Liège, Liège, Belgium.

Clauzet, M., M. Ramires, and A. Begossi. 2007. Etnoictiologia dos Pescadores Artesanais da Praia de Guaibim, Valença (BA), Brasil. Neotropical Biology and Conservation 2:136-154.

Colfer, C. J. P., R. L. Wadley, and P. Venkateswarlu. 1999. Understanding Local People's Use of Time: a Pre-condition for Good Co-management. Environmental Conservation 26:41-52. DOI:10.1017/ s0376892999000077.

Djidohokpin, G., E. Sossoukpè, Z. Sohou, J. L. Tamesse, and E. D. Fiogbé. 2017. Ichthyofauna of Tovè River in the South Benin: Specific Diversity and Spatial Distribution. South Asian Journal of Life Sciences 5:19-29.
FAO. 2008. Benin. Country Profile. Available at: http://www.fao.org/countryprofiles/index/en/? iso3=BEN. Accessed on Jun 26, 2020.

Froese, R., and D. Pauly, eds. 2017. FishBase [web page]. Available at: https://www.fishbase.se/ search.php. Accessed on December 18, 2019.

Gadgil, M., F. Berkes, and C. Folke. 1993. Indigenous Knowledge for Biodiversity Conservation. Ambio 22:151-156.

Imorou Toko, I. 2007. Amélioration de la Production Halieutique des Trous Traditionnels à Poissons (Whédo) du Delta de l'Ouémé (Sud Bénin) par la Promotion de l'Elevage des Poissons-chats Clarias gariepinus et Heterobranchus longifilis. Unpublished Doctoral Dissertation, Facultés universitaires Notre -Dame de la Paix-Namur, Namur, Belgium.

Johannes, R. E. 1978. Traditional Marine Conservation Methods in Oceania and their Demise. Annual Review of Ecology and Systematics 9:349-364. DOI:10.1146/annurev.es.09.110178.002025.

Johannes, R. E. 1981. Working with Fishers to Improve Coastal Tropical Fisheries and Resource Management. Bulletin of Marine Science 31:673-680.

Johannes, R. E. 1993. Integrating Traditional Ecological Knowledge and Management with Environmental Impact Assessment. In Traditional Ecological Knowledge: Concepts and Cases, edited by J. T. Inglis, pp. 33-39. Canadian Museum of Nature, Ottawa, Canada.

Johannes, R. E., M. M. R. Freeman, and R. J. Hamilton. 2000. Ignore Fishers' Knowledge and Miss the Boat. Fish and Fisheries 1:257-271. DOI:10.1111/j.1467-2979.2000.00019.x.

Lalèyè, A. P., A. Chikou, J-C. Philippart, G. Teugels and P. Vandewalle. 2004. Étude de la Diversité Ichtyologique du Bassin du Fleuve Ouémé au Bénin (Afrique de l'Ouest). Cybium 28:329-339.

Lalèyè, A. P., A. Ezin., P. Vandewalle, J-C. Phillippart, G. G. Teugels. 2007. Caractéristiques de la Pêche dans le Fleuve Ouémé au Bénin (Afrique de l'Ouest). Journal of Afrotropical Zoology (Special Issue) 137-148.

Leite, M. C. F, and M. A. Gasalla. 2013. A Method for Assessing Fishers' Ecological Knowledge as a Practical Tool for Ecosystem-Based Fisheries Management: Seeking Consensus in Southeastern 
Brazil. Fisheries Research 145:43-53. DOI:10.1016/ j.fishres.2013.02.013.

Lima, M. S. P., J. E. Lins Oliveira, M. F. de Nóbrega, and P. F. M. Lopes. 2017. The use of Local Ecological Knowledge as a Complementary Approach to Understand the Temporal and Spatial Patterns of Fishery Resources Distribution. Journal of Ethnobiology and Ethnomedicine 13:30. DOI:10.1186/s13002-017-0156-9.

Marques, J., and G. Wanderley. 1991. Aspectos Ecologicos na Ecologia dos Pescadores, do Camplexo Estuarino-Lagunar de MundauManguaba Alagoas. Universida de EstaduaI de Campinas, Instituto de Biologia, Campinas, Sâo Paulo, Brazil.

Medin, D. L., N. O. Ross, S. Atran, D. Cox, J. Coley, J. B. Proffitt, and S. Blok. 2006. Folkbiology of Freshwater Fish. Cognition 99:237-273. DOI:10.1016/j.cognition.2003.12.005.

Micha, J. C., and V. Frank. 1976. Biologie des Principales Espèces Utilisées en Pisciculture Africaine. CIFA Tech. Paper no. 4, supplement 1, pp. 292-331. Symposium Aquaculture in Africa 1975, Accra, Ghana.

Neuenschwander, P., B. Sinsin, and G. Goergen, eds. 2011. Nature Conservation in West Africa: Red List for Benin. International Institute of Tropical Agriculture, Ibadan, Nigeria.

Oberndorfer, E., N. Winters, C. Gear, G. Ljubicic, and J. Lundholm. 2017. Plants in a "Sea of Relationships": Networks of Plants and Fishing in Makkovik, Nunatsiavut (Labrador, Canada). Journal of Ethnobiology 37:458-477. DOI:10.2993/0278-0771 -37.3.458.

Oishi, T. 2016. Ethnoecology and Ethnomedicinal Use of Fish among the Bakwele of Southeastern Cameroon. Revue d'Ethnoécologie 10. DOI:10.4000/ ethnoecologie.2893.

Paz, V. A., and A. Begossi. 1996. Ethnoichthyology of Galviboa Fishermen of Sepetiba Bay, Brazil. Journal of Ethnobiology 16:157-168.
Poizat, G., and E. Baran. 1997. Fishermen's Knowledge as Background Information in Tropical Fish Ecology: A Quantitative Comparison with Fish Sampling Results. Environmental Biology of Fishes 50:435-449.

Posey, D. A. 1983. Indigenous Knowledge and Development: An Ideological Bridge to the Future. Ciência e Cultura 35:877-894.

Seixas, C. S., and A. Begossi. 2001. Ethnozoology of Fishing Communities from Ilha Grande (Atlantic Forest Coast, Brazil). Journal of Ethnobiology 21:107135

Silvano, R. A. M., and A. Begossi. 2010. What Can Be Learned from Fishers? An Integrated Survey of Fishers' Ecological Knowledge and Bluefish (Pomatomus saltatrix) Biology on the Brazilian Coast. Hydrobiology 637:3-18. DOI:10.1007/s10750-0099979-2.

Sohou, Z., R. C Houedjissin, and N. R. A. Ahoyo. 2009. La Pisciculture: De la Tradition à la Modernisation. Bulletin de Recherche Agronomique du Bénin 66:48-59.

Turner, N. J., and F. Berkes. 2006. Coming to Understanding: Developing Conservation through Incremental Learning in the Pacific Northwest. Human Ecology 34:495-513. DOI :10.1007/s10745006-9042-0.

UNDP Bénin. 2015. Rapport National sur le Développement Humain 2014-2015: Agriculture, Sécurité Alimentaire et Développement Humain au Bénin. Le Programme des Nations Unies pour le développement (PNUD) et le Gouvernement de la République du Bénin, Cotonou, Bénin.

Welcomme, R. L. 1971. Evolution de la Pêche Intérieure, son Etat Actuel et ses Possibilités. FAO/ UNDP 2938, Rome.

Wester, L., and S. Yongvanit. 1995. Biological Diversity and Community Lore in Northeastern Thailand. Journal of Ethnobiology 15:71-88. 